\title{
Sunitinib és zoledronsav által indukált állcsont-osteonecrosis
}

\author{
Soós Balázs dr. - Vajta László dr. - Szalma József dr. \\ Pécsi Tudományegyetem, Fogorvos-tudományi Kar, Arc-, Állcsont- és Szájsebészeti Tanszék, Pécs
}

\begin{abstract}
Napjainkban egyre gyakrabban találkozunk biszfoszfonátok, illetve egyéb, nem biszfoszfonát típusú antireszorptív, illetve angiogenezis-gátló gyógyszerek által indukált állcsont-osteonecrosissal. E betegkör kezelése komoly szakmai kihívást jelent a fogorvosok, dentoalveolaris és maxillofacialis sebészek számára. Kiemelkedően fontos a megelőzés, aminek alapja a gyógyszereket elrendelő szakorvosok felkészültsége, általuk a betegek fogorvosi vizsgálatra irányítása, a kezelést megelőzően fogászati gócszanálás kérése, orális higiénére nevelés, edukáció, majd a szoros fogorvosi ellenőrzés, illetve a már kialakult állcsont-osteonecrosis esetén a beteg maxillofacialis szakrendelésre irányítása. A szerzők egy sunitinib és zoledronsav kombinált terápiában részesülő állcsont-osteonecrosisban szenvedő nôbeteg konzervatív, később sebészi kezelésének nehézségeit mutatják be. A hat és tizenkét hónapos kontrollon a beteg panasz- és tünetmentesnek mutatkozott, az operált terület gyógyult. A hosszú távú sikeresség megállapításához a beteg további követésére lesz szükség. Orv. Hetil., 2015, 156(46), 1865-1870.
\end{abstract}

Kulcsszavak: állcsont-osteonecrosis, biszfoszfonát, sunitinib, zoledronsav

\section{Sunitinib and zoledronic acid induced osteonecrosis of the jaw}

\section{Case report}

The tendency for bisphosphonate and non-bisphosphonate (eg.: antiresorptive or anti-angiogenesis drugs) induced osteonecrosis is increasing. Treatment of these patients is a challenge both for dentists and for oral and maxillofacial surgeons. Cooperation with the drug prescribing general medicine colleagues to prevent osteonecrosis is extremely important. Furthermore, prevention should include dental focus elimination, oral hygienic instructions and education, dental follow-up and, in case of manifest necrosis, referral to maxillofacial departments. Authors outline the difficulties of conservative and surgical treatment of a patient with sunitinib and zoledronic acid induced osteonecrosis. The patient became symptomless and the operated area healed entirely six and twelve months postoperatively. A long term success further follow-up is necessary to verify long-term success.

Keywords: osteonecrosis of the jaw, bisphosphonate, sunitinib, zoledronic acid

Soós, B., Vajta, L., Szalma, J. [Sunitinib and zoledronic acid induced osteonecrosis of the jaw. Case report]. Orv. Hetil., 2015, 156(46), 1865-1870.

(Beérkezett: 2015. szeptember 9.; elfogadva: 2015. szeptember 24.)

\begin{abstract}
Rövidítések
AAOMS = American Association of Oral and Maxillofacial Surgeons; BRONJ = (bisphosphonate-related osteonecrosis of the jaw) biszfoszfonát indukálta állcsont-osteonecrosis; Er:YAG lézer $=($ erbium-doped yttrium aluminium garnet laser $)$ lézerablatio keménylézerrel; MRONJ = (medication-related osteonecrosis of the jaw) gyógyszer indukálta állcsont-osteonecrosis; $\mathrm{Nd}: Y A G=$ (neodymium-doped yttrium aluminium granet laser) lágylézeres biostimuláció, diódalézer; PRF $=$ (platelet rich fibrin) thrombocytában gazdag fibrin; RANK-L = receptor activator of nuclear factor kappa $\beta$-ligand; VEGF $=($ vascular endothelial growth factor) vascularis endothelialis növekedési faktor
\end{abstract}

Az egyre szélesebb körben alkalmazott és mostanra jól ismert, esetleges állcsont-osteonecrosis mellékhatással bíró biszfoszfonát-gyógyszercsoport mellett egyre gyakrabban alkalmaznak hasonló mellékhatással fenyegető, nem biszfoszfonát típusú gyógyszereket a daganatos, illetve csontritkulással küzdő betegek kezelésében. Ilyen gyógyszertípusok a csontreszorpciót gátló hatású, a receptor activator of nuclear factor kappa $\beta$-ligand (RANK-L) elleni antitest, a denosumab, illetve az antiangiogén hatással bíró vascularis endothelialis növekedési faktor (vascular endothelial growth factor - VEGF) inhibitor bevacizumab, valamint a tirozinkináz-inhibitor 
sunitinib. Ezen gyógyszerek önállóan vagy biszfoszfonátokkal kombinálva alkalmazhatók. Kombinációjuk csökkentheti a manifesztációig eltelő időt, növeli az osteonecrosis kialakulásának esélyét, illetve súlyosbíthatja azt $[1,2]$.

A tirozinkináz-inhibitorok közé tartozó sunitinibet gastrointestinalis stromalis tumor, kis sejtes tüdőrák, pajzsmirigy-carcinoma, illetve malignus hematológiai kórképek kezelésére alkalmazzák. Egyik súlyos mellékhatása az állcsont-osteonecrosis kialakulása lehet [3].

$\mathrm{Az}$ amerikai szájsebészeti társaság (American Association of Oral and Maxillofacial Surgeons - AAOMS) 2014-ben kiegészített ajánlása alapján a biszfoszfonát indukálta állcsont-osteonecrosis (bisphosphonate-related osteonecrosis of the jaw - BRONJ) megnevezés helyett javasolt a gyógyszer indukálta állcsont-osteonecrosis (medication-related osteonecrosis of the jaw - MRONJ) megnevezés használata. A MRONJ diagnózishoz három kritériumnak kell teljesülni: 1. korábbi vagy jelenleg alkalmazott antireszorptív vagy antiangiogén gyógyszeres kezelés; 2 . legalább 8 hete fennálló denudált, illetve extra- vagy intraoralis fistulán át szondázható csontfelszín; 3. az anamnézisben az állcsontokat is terhelő sugárterápia hiánya [4].

A MRONJ rizikótényezőit három nagy csoportba lehet sorolni. Ezek lehetnek gyógyszereléssel kapcsolatos (gyógyszer típusa, dózisa, adásmódja, alkalmazás gyakorisága, időtartama), szisztémás (szteroidok, immunszuppresszánsok, antiangiogének vagy antiösztrogén) gyógyszerek együttes alkalmazása, malignus betegségek (például emlőrák, prosztatarák, myeloma multiplex, diabetes mellitus, osteoporosis), valamint lokális (orális higiéné, anatómiai sajátosságok, dentoalveolaris beavatkozások, nyálkahártya-irritáció) faktorok $[5,6,7]$.

A MRONJ megjelenése alapján négy stádiumba sorolható: 0. stádium: Nincs denudált, illetve extra- vagy intraoralis fistulán át szondázható csontfelszín, csak egyéb nem specifikus tünetek vannak. Elsö stádium: Denudált, illetve extra- vagy intraoralis fistulán át szondázható csontfelszín található, lágyrész-gyulladás és fájdalom nélkül. Második stádium: Amikor az 1. stádium képéhez társul a területet övező lágy részek gyulladása és fájdalom. Harmadik stádium: A 2. stádium képéhez kapcsolódik minimum egy az alábbi súlyos elváltozások közül, úgymint patológiás csonttörés, extraoralis fistula, a crista zygomaticoalveolaréig, a ramus mandibulaeig, az arcüregig vagy a mandibula bázisáig terjedő necrosis, radiológiailag kimutatható nagymértékű osteolysis [8]. A stádiumbeosztástól függően különböző konzervatív, illetve sebészi kezelési stratégiákat is ajánlanak, de ezzel kapcsolatban egységes állásfoglalás még nem született $[4,9]$.

A következőkben célul tűztük ki egy l. stádiumú sunitinib és zoledronsav kombinált kezelés által indukált állcsont-osteonecrosisban szenvedő beteg esetén keresztül az irodalomban fellelhető kezelési ajánlások összefoglalását.

\section{Esetismertetés}

Esetbemutatásunk alanya egy 42 éves nőbeteg. Általános anamnézisében 1998-ban elvégzett gyomordaganat miatti gastrectomia és kemoterápia, valamint metasztatikus májdaganat szerepel. Jelentkezésekor a páciens sunitinib és levo-thyroxin terápiában részesült. 2012-ben egy ciklus intravénás zoledronátot kapott. Gyógyszerérzékenységről a beteg nem tud.

A beteg 2013 októberében jelentkezett klinikánkon gyógyulási hajlamot nem mutató posztextrakciós sebbel (1. ábra). Jobb alsó második őrlőfogának extrakciójára profilaktikus antibiotikus védelem s egyéb óvintézkedések nélkül 2013 szeptemberében került sor magánfogorvosi ellátás keretében. A sebet kezdetben konzervatívan kezeltük, kéthetente, majd aztán heti rendszerességgel 3\%-os hidrogén-peroxid-oldattal átöblítettük, valamint jodoformos drénnel láttuk el. 2014 áprilisában sebészeti küret beavatkozást végeztünk. A beavatkozást megelőző harmadik napon megkezdett egyhetes antibiotikus profilaxist alkalmazva helyi érzéstelenítésben a 4.7-es fogmeder területét Wassmund-lebennyel feltártuk, necrectomiát, sequestrectomiát végeztünk. A mútét során eltávolított csontszövetet és lágyrészt szövettani elemzésre bocsátottuk - a szakmai irányelveknek megfelelően - az alapbetegség propagációjának kizárása céljából [4]. A fogmedret a beteg vénás véréból frissen centrifugált thrombocytában gazdag fibrin- (platelet rich fibrin PRF) preparátummal töltöttük fel, majd a trapézlebeny megnyújtását követően 4.0-ás szintetikus fonallal primer sebzárást végeztünk. Varratszedésnél 10 nap múlva a seb szétnyílt, záródási hajlamot nem mutatott. Mivel az elváltozás a betegnek fájdalmat nem okozott és a gyulladásos jelek hiányoztak, a konzervatív terápia (hetente 3\%os hiperolos sebtoalett és jodoformos dréncsere) folytatása mellett döntöttünk.

2014 júniusában a páciens 3.6-os foga vált panaszossá. A fog prognózisa a régi gyökércsatorna-preparációs sikertelenségek, a nem kielégítő gyökértömés és az idült gyulladásos jelek miatt reménytelennek bizonyult, így a kockázatok alapos mérlegelése és a páciens teljes körú tájékoztatása után, a páciens kérésére, a fogat eltávolítottuk. A páciensnek otthonában a beavatkozás előtti és az azt követő két hétre napi 2-szeri 0,2\%-os klór-hexidines (Corsodyl, GlaxoSmithKline, Magyarország) öblögetést javasoltunk. A beavatkozást antibiotikus profilaxisban, a beavatkozást megelőző egy héttel elkezdett, két hétig alkalmazott $2 \times 875 \mathrm{mg} / 125 \mathrm{mg}$ amoxicillin/klavulánsav (Augmentin Duo 1 g, GlaxoSmithKline, Magyarország), kombinálva $3 \times 250 \mathrm{mg}$ metronidazollal (Klion $250 \mathrm{mg}$, Richter Gedeon, Magyarország) végeztük el. Az alveolus excochleatiót követően hiperolos átöblítést és jodoformos drenázst alkalmaztunk, amelyet hetente ismételtünk. A seb gyógyhajlamot azóta sem mutatott (1. stádiumú elváltozás), jelenleg panaszmentes, nem progrediál, sebészi kezelést még nem tervezünk. 


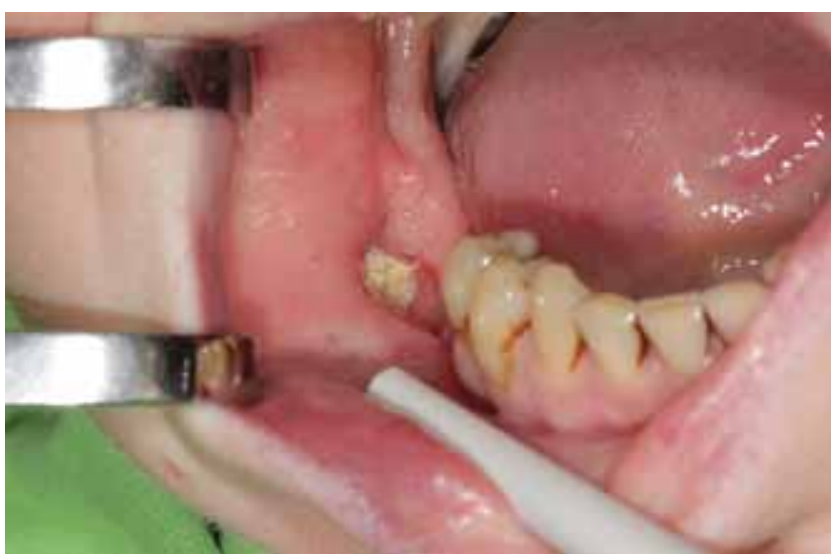

1. ábra $\quad$ Nem gyógyuló extrakciós seb és denudált, necroticus csontrész let a jobb alsó második őrlőfog helyén

2014 augusztusában a beteg jelezte, hogy megterhelőnek érzi a rendszeres 14 naponta végzett kontrollvizsgálatot, ezért kérésére a jobb alsó kvadránsban a mandibula marginális reszekciója mellett döntöttünk. A beavatkozást megelőző egy héttel elkezdett, két hétig alkalmazott - fentebb részletezett - antibiotikus védelemben és antiszeptikus szájöblögető használata mellett, a jobb alsó második őrlőfog helyén kialakult denudált terület borítéklebenyes feltárásakor piezoelektromos sebészi készülék (W\&H Piezomed, Ausztria) segítségével, körülbelül $5 \mathrm{~mm}$ széles biztonsági zónával, marginális reszekciót hajtottunk végre (2. ábra). A mưtéti preparátum eltávolítása után az éles csontszéleket lesimítottuk, a gyulladt nyálkahártyaszegélyt az épben kimetszettük, majd a sebet 4.0-ás szintetikus (nejlon) monofil fonallal primeren zártuk (3. ábra). Az eltávolított csontszövetet ismét patohisztológiai elemzésre bocsátottuk (4. ábra). A posztoperatív ödémától eltekintve a lábadozás időszaka eseménytelenül zajlott. Az egy és három hónapos, majd a fél- és egyéves kontrollon az operált terület panaszmentesnek és gyógyultnak mutatkozott (5. ábra).

\section{Megbeszélés}

A biszfoszfonátot kapó betegek mellett a fogorvosok fokozott figyelmét igényli a következő készítmények valamelyikét kapó betegkör: denosumab (Prolia, Amgen Europe B.V., Hollandia; Xgeva, Amgen Europe B.V., Hollandia), sunitinib (Sutent, Pfizer, Amerikai Egyesült Államok), bevacizumab (Avastin, Roche Registration, Egyesült Királyság). Ezen gyógyszerek biszfoszfonáttal

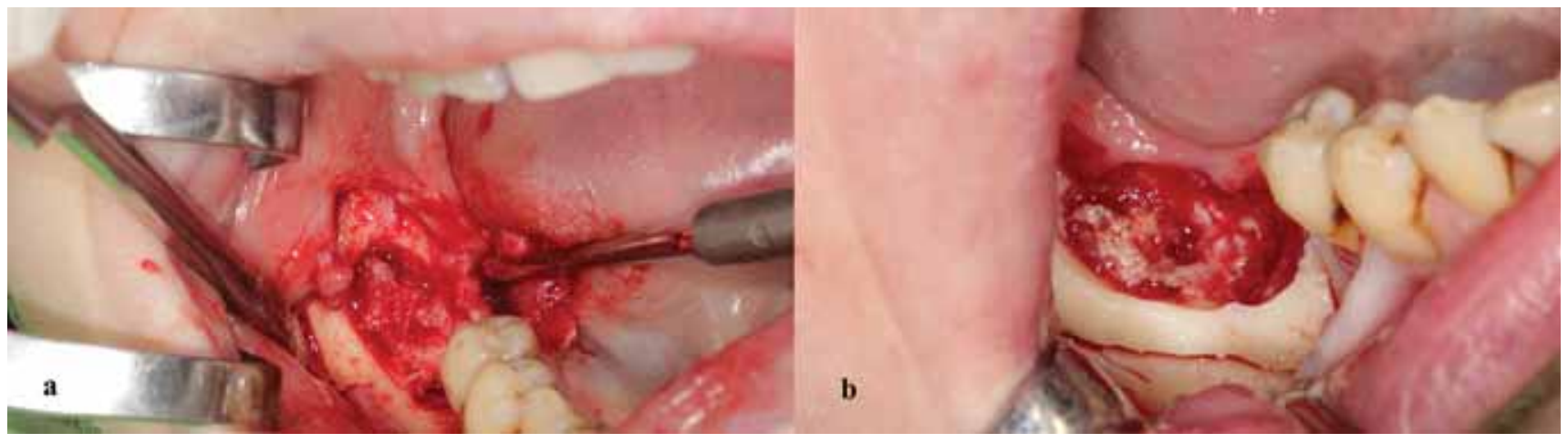

2. ábra $\quad$ a) A necrosis feltárása teljes vastagságú mucoperiostealis lebenyból. b) A reszekciós szélek meghatározása piezoelektromos preparálással

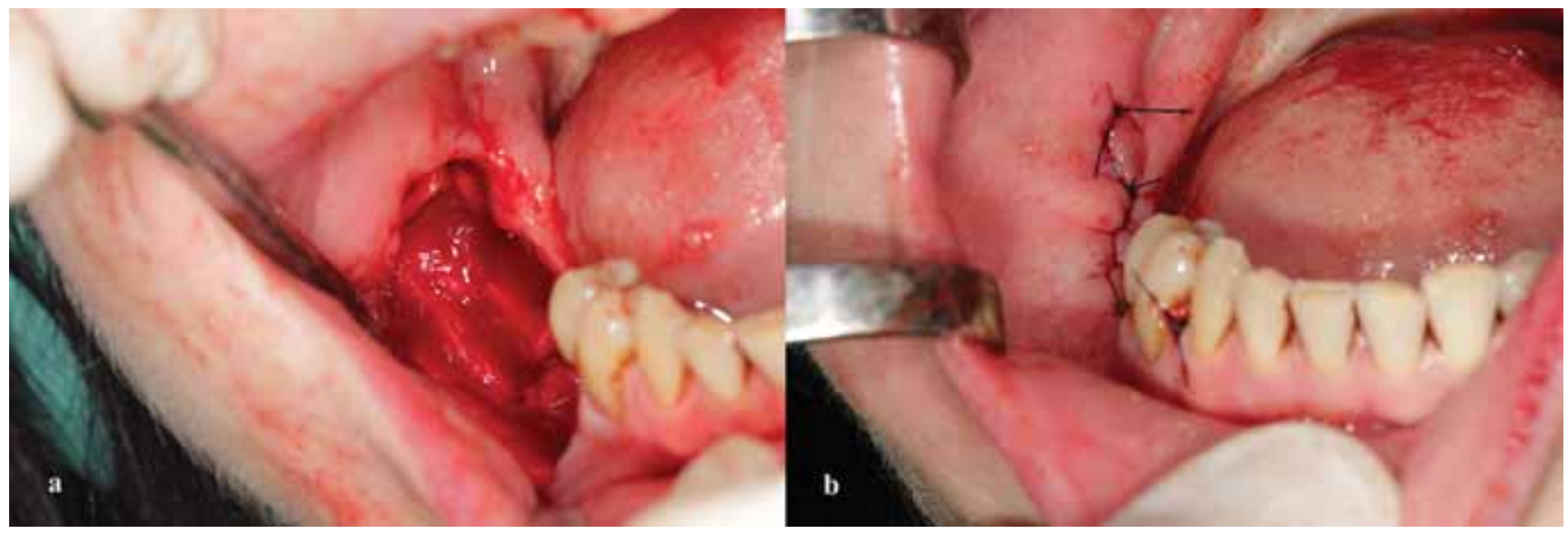

3. ábra $\quad$ a) A csontreszekátum eltávolítása után megfigyelhető a jó vérellátású ép csontfelszín. b) A mútéti terület per primam sebzárás után. A gyulladt marginális lágyrészek előzetesen kimetszésre kerültek 

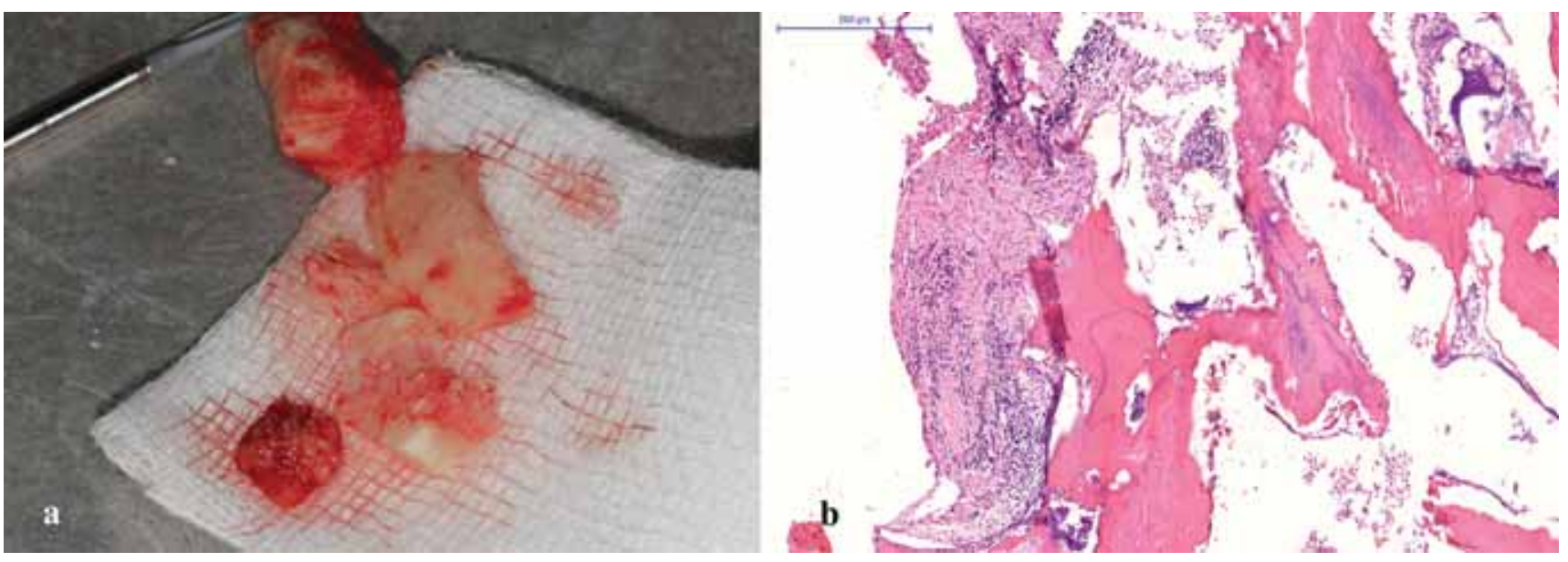

4. ábra

a) A feltárás során reszekált csont. b) Kórszövettani képen necroticus, reszorpciós trabecularis csontállomány látható, reaktív lobos, fibroticus kötőszövet-szaporulattal, HE-festés mellett

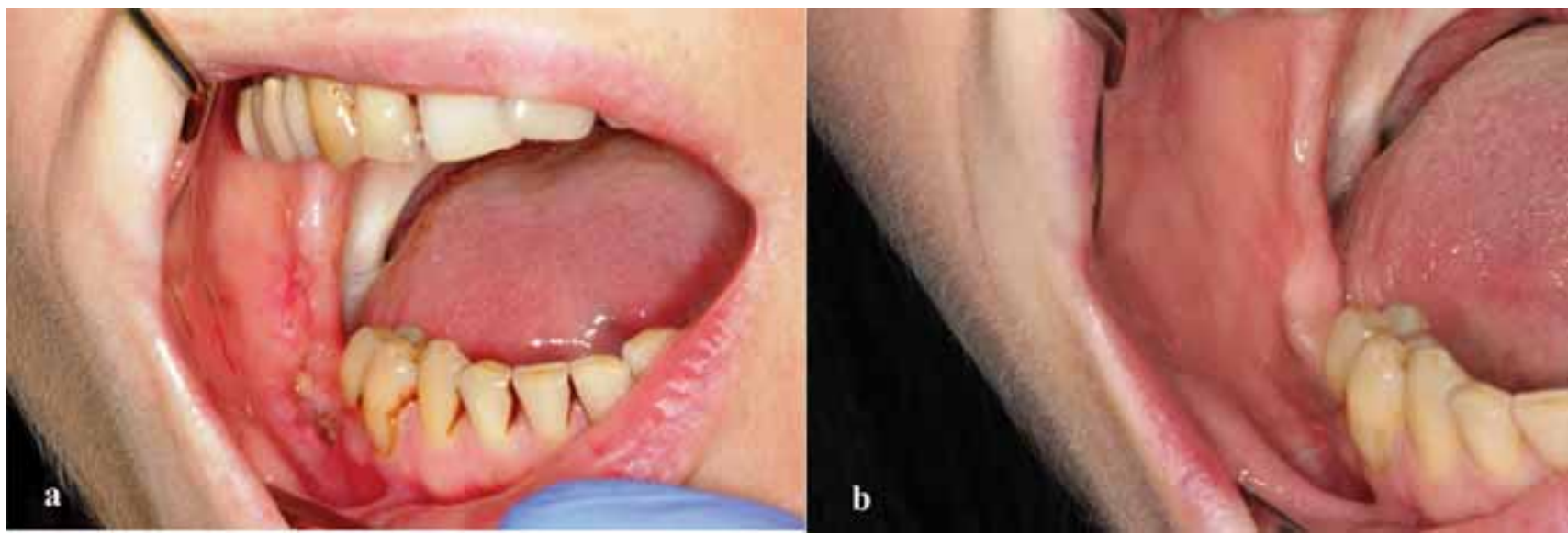

5. ábra

a) A kéthetes posztoperatív képen lebenydehiscentia látható, amelyból a csontfelszíneket szondázással nem tudtuk tapintani. b) Egyéves posztoperatív képen a seb reakció- és panaszmentes. Denudált és/vagy necroticus csontfelszín nem látható

való kombinációja nagyban növeli a MRONJ kialakulási valószínúségét, illetve súlyosságát $[1,2]$. Alapvetően fontos e betegcsoport szoros fogorvosi kontrollja, alapos szájhigiéné fenntartása, lehetőség szerint konzervatív fogászati beavatkozások választása.

Amennyiben elkerülhetetlen a fogeltávolítás, a kivitelezésére többféle protokoll alakult ki. Egyes szerzők szerint az extrakció tervezésétől kezdve napi egyszer javasolt 0,2\%-os klórbexidines öblögetés, szükség esetén két-három héttel a beavatkozás előtt professzionális szájhigiénés kezelés. A sebészi beavatkozás előtt három nappal antibiotikus profilaxis ( 8 óránként $1 \mathrm{~g}$ amoxicillin, vagy penicillinérzékenység esetén egyéb széles spektrumú antibiotikum) kezdése javasolt, majd további 17 napig folytatandó. Az extrakció mucoperiostealis trapézlebenyes feltárásból, minimális traumával, a fogmeder alapos kikaparásával, majd feszülésmentes primer sebzárással végzendő. Egy hét múlva javasolt a varratszedés, továbbá két hétig 1\%-os klórbexidines gél napi háromszori alkalmazása. Javasolt 1, 2, 4 hetes, 2, 3, 6, majd 12 hónapos kontroll [10]. Más szerzők szerint az extrakció előtt két héttel elvégzendők a professzionális szájhigiénés beavatkozások, majd a beavatkozást megelőző este javasolt antibiotikus profilaxist ( 8 óránként $1 \mathrm{~g}$ amoxicillin/klavulánsav, vagy penicillinérzékenység esetén 8 óránként 600 mg eritromicin) kezdeni, s 6 napig folytatni. Az extrakció minimális traumával végzendő, majd javasolt a fogmeder 2 percig tartó tisztítása, valamint az éles csontszélek lesimítása, mindkettő piezoelektromos készülék segítségével [11]. Ajánlott továbbá a fogmeder feltöltése PRF-preparátummal, valamint a sebszélek közelítése módosított horizontális matracöltésekkel. Három napig az érintett terület környezetének tisztítása javasolt napi háromszor, 3\%-os hidrogén-peroxid-oldattal átitatott gézlappal. A varratszedés ajánlott időpontja egy hét elteltével. Javasolt 1, 3, 6, majd 12 hónapos kontroll [12].

Amennyiben posztextrakciós necrosis alakul ki, stádiumtól függően különböző beavatkozások közül választhatunk. A konzervatív kezelési eljárások (antimikrobiális öblögetés, antibiotikum-kúra, hyperbaricus oxigénterá- 
pia, lágylézeres biostimuláció, szubkután injektálható paratiroidhormon-függő protein vagy bortezomib alkalmazása) fóleg a betegség progressziójának lassítását, illetve az exponált csontfelszín felülfertőződésének megelőzését célozzák [13, 14, 15, 16, 17]. Az antimikrobiális öblögetés és antibiotikum-kezelés csupán mintegy 25-50\%-ban eredményeznek gyógyulást, szemben a sebészeti eljárások akár $85 \%$-ot meghaladó sikerességével $[18,19,20,21,22,23]$.

A sebészi beavatkozások (sequestrectomia, debridement, reszekció, lézerablatio) sikeressége leginkább az operatőr jártasságától függ [24]. A csontelvétel kivitelezésére három fő lehetőségünk van. A hagyományos forgácsolómüszerek és piezoelektromos sebészi készülék mellett keménylézer alkalmazása is lehetséges. A sequestrectomia a csontsequester eltávolítását, a debridement a csontnecrosis felszíni rétegének simítását jelenti. Céljuk a nyálkahártya-gyógyulás elősegítése. A reszekció (marginális, szegmentális, szubtotális, illetve totális) a necroticus rész épben történő kimetszését jelenti, a laesio teljes eltávolítását célozza. Nagyon lényeges, hogy a reszekció kellően mélyen, az épben történjen, a lehető legtöbb egészséges szövet megkímélése mellett. A reszekciós szél meghatározásánál fontos a preoperatív tervezés képalkotók (periapicalis röntgenfelvétel, panoráma-röntgenfelvétel, komputertomográfiás felvétel, mágneses rezonanciás felvétel, csontszcintigráfia) segítségével, illetve maga az intraoperatív kép. A szem ellenőrzése mellett történő reszekciós szél megállapításához nyújt segítséget a tetraciklinfluoreszcenciás módszer, amely segít a fluoreszcens tetraciklinszármazékot halmozó, így gerjesztő lámpával megvilágítva a zölden fluoreszkáló vitális csont és a nem fluoreszkáló necroticus csontszövet pontos megkülönböztetésében [24]. A csontmanipulációk elvégzéséhez sokan a piezoelektromos sebészeti készülék használatát javasolják, mivel a MRONJ patogenezisének egyik feltételezett összetevője a bakteriális biofilmképződés. A készülék múködése során a folyadékban keltett nagy sebességű áramlás hatására számos gázbuborék képződik, amelyek a nagyobb környező nyomás hatására kollabálnak, ennek következtében az összecsapódó folyadék nagy energiájú lökéshullámot kelt (kavitáció), ami a baktériumok sejthártyáját megrongálva fejti ki baktericid hatását [25, 26]. A lézerablatio keménylézerrel (erbiumdoped yttrium aluminium garnet laser - Er:YAG lézer) történő anyagelvétel, amelyet kiegészíthetünk lágylézeres biostimulációval (diódalézerrel vagy neodymiumdoped yttrium aluminium granet laser - Nd:YAG lézerrel), ami fokozza a sejtszaporodást, az osteoblastok szaporodását és differenciálódását, illetve az érképződést, amely növeli a csont és a nyálkahártya gyógyhajlamát $[27,28,29]$. Használata a beteg számára kevésbé megterhelő, mivel lebenyképzést nem igényel, kevésbé fájdalmas, kevesebb vérzéssel jár [30]. Amennyiben a beteg általános egészségi állapota miatt ellenjavallt a sebészi beavatkozás, a konzervatív terápia akár 70\%-os sike- rességgel, de sajnos sokszor csak átmenetileg, javíthatja vagy megállíthatja a betegséget [31].

$\mathrm{Az}$ állcsontnecrosis 0 . és 1 . stádiumában konzervatív kezelés - antimikrobiális öblögetés (napi kétszer klórhexidin 0,12-2\%), antibiotikus kúra $(2 \times 1$ amoxicillin/ klavulánsav $875 \mathrm{mg} / 125 \mathrm{mg}, 3 \times 1$ metronidazol 250 mg) - javasolt. A 2. és 3. stádiumú elváltozás esetén hagyományos sebészeti (sequestrectomia, debridement) vagy kiterjesztett sebészeti (reszekció) eljárások alkalmazása jön szóba. Adjuváns kezelésként bármely stádiumban jó hatású lehet a hyperbaricus oxigénterápia, az ózonterápia, a lágylézeres biostimuláció, a szubkután injektálható paratiroidhormon-függő protein vagy bortezomib alkalmazása [9, 30].

Esetismertetésünkkel szerettük volna felhívni a figyelmet a MRONJ kezelésének és gyógyíthatóságának nehézségeire, amely miatt jelentős felelősség hárul az egészségügyi ellátókra, hogy minden erőfeszítésükkel a prevenciós lehetőségeket támogassák.

Anyagi támogatás: A közlemény megírása anyagi támogatásban nem részesült.

Szerzôi munkamegosztás: S. B., V. L.: Az eset ellátása, a cikk megírása. Sz. J.: A kezelési terv meghatározása, a cikk megírása. A közlemény végleges változatát mindhárom szerző elolvasta és jóváhagyta.

Érdekeltségek: A szerzőknek nincsenek érdekeltségeik.

\section{Köszönetnyilvánítás}

A jelen tudományos közleményt a szerző́k a Pécsi Tudományegyetem alapításának 650. évfordulója emlékének szentelik. Köszönjük a patológiai elemzést Dr. Fincsur Andrásnak, a PTE ÁOK Pathologiai Intézet munkatársának.

\section{Irodalom}

[1] Christodoulou, C., Pervena, A., Klouvas, G., et al.: Combination of bisphosphonates and antiangiogenic factors induces osteonecrosis of the jaw more frequently than bisphosphonates alone. Oncology, 2009, 76(3), 209-211.

[2] Troeltzsch, M., Woodlock, T., Kriegelstein, S., et al.: Physiology and pharmacology of nonbisphosphonate drugs implicated in osteonecrosis of the jaw. J. Can. Dent. Assoc., 2012, 78, c85.

[3] Arora, A., Scholar, E. M.: Role of tyrosine kinase inhibitors in cancer therapy. J. Pharmacol. Exp. Ther., 2005, 315, 971-979.

[4] Ruggiero, S. L., Dodson, T. B., Fantasia, J., et al.: American Association of Oral and Maxillofacial Surgeons position paper on medication-related osteonecrosis of the jaw - 2014 update. J. Oral Maxillofac. Surg., 2014, 72(10), 1938-1956.

[5] Dimopoulos, M. A., Kastritis, E., Bamia, C., et al.: Reduction of osteonecrosis of the jaw (ONJ) after implementation of preventive measures in patients with multiple myeloma treated with zoledronic acid. Ann. Oncol., 2009, 20(1), 117-120.

[6] Bamias, A., Kastritis, E., Bamia, C., et al.: Osteonecrosis of the jaw in cancer after treatment with bisphosphonates: incidence and risk factors. J. Clin. Oncol., 2005, 23(34), 8580-8587. 
[7] Vaszilkó, M., Kovács, E., Restár, L., et al.: Potential significance of antiestrogen therapy in the development of bisphosphonate related osteonecrosis of the jaw. J. Craniomaxillofac. Surg., 2014, 42(8), 1932-1936.

[8] Ikeda, T., Kuraguchi, J., Kogashiwa, Y., et al.: Successful treatment of Bisphosphonate-Related Osteonecrosis of the Jaw (BRONJ) patients with sitafloxacin: new strategies for the treatment of BRONJ. Bone, 2015, 73, 217-222.

[9] Rupel, K., Ottaviani, G., Gobbo, M., et al.: A systematic review of therapeutical approaches in bisphosphonates-related osteonecrosis of the jaw (BRONJ). Oral Oncol., 2014, 50(11), 1049-1057.

[10] Lodi, G., Sardella, A., Salis, A., et al.: Tooth extraction in patients taking intravenous bisphosphonates: a preventive protocol and case series. J. Oral Maxillofac. Surg., 2010, 68(1), 107-110.

[11] Blus, C., Szmukler-Moncler, S., Giannelli, G., et al.: Use of ultrasonic bone surgery (piezosurgery) to surgically treat bisphosphonate-related osteonecrosis of the jaws (BRONJ). A case series report with at least 1 year of follow-up. Open Dent. J., 2013, 7, 94-101.

[12] Scoletta, M., Arata, V., Arduino, P. G., et al.: Tooth extractions in intravenous bisphosphonate-treated patients: a refined protocol. J. Oral Maxillofac. Surg., 2013, 71(6), 994-999.

[13] Freiberger, J. J., Padilla-Burgos, R., Chboeu, A. H., et al.: Hyperbaric oxygen treatment and bisphosphonate-induced osteonecrosis of the jaw: a case series. J. Oral Maxillofac. Surg., 2007, 65(7), 1321-1327.

[14] Harper, R. P., Fung, E.: Resolution of bisphosphonate-associated osteonecrosis of the mandible: possible application for intermittent low-dose parathyroid hormone $[\operatorname{rhPTH}(1-34)]$. J. Oral Maxillofac. Surg., 2007, 65(3), 573-580.

[15] Timură̆aoğlu, A., Ozkaynak, C., Tuzuner, S., et al.: Improvement of zoledronic-acid-induced jaw osteonecrosis with bortezomib. Acta Haematol., 2007, 118(4), 203-204.

[16] Vescovi, P., Merigo, E., Manfredi, M., et al.: Nd:YAG laser biostimulation in the treatment of bisphosphonate-associated osteonecrosis of the jaw: clinical experience in 28 cases. Photomed. Laser Surg., 2008, 26(1), 37-46.

[17] Ripamonti, C., Maniezzo, M., Ghiringhelli, R., et al.: Medical ozone oil suspension applications heal osteonecrosis of the jaws (ONJS) in patients treated with bisfosfonates (BPS). Preliminary results of a single institution protocol. Breast, 2009, 18(1), S67S68.

[18] O'Ryan, F. S., Khoury, S., Liao, W., et al.: Intravenous bisphosphonate-related osteonecrosis of the jaw: bone scintigraphy as an early indicator. J. Oral Maxillofac. Surg., 2009, 67(7), 13631372.

[19] Watters, A. L., Hansen, H. J., Williams, T., et al.: Intravenous bisphosphonate-related osteonecrosis of the jaw: long-term follow-up of 109 patients. Oral Surg. Oral Med. Oral Pathol. Oral Radiol., 2013, 115(2), 192-200.
[20] Badros, A., Terpos, E., Katodritou, E., et al.: Natural history of osteonecrosis of the jaw in patients with multiple myeloma. J. Clin. Oncol., 2008, 26(36), 5904-5909.

[21] Van den Wyngaert, T., Claeys, T., Huizing, M. T., et al.: Initial experience with conservative treatment in cancer patients with osteonecrosis of the jaw $(\mathrm{ONJ})$ and predictors of outcome. Ann. Oncol., 2009, 20(2), 331-336.

[22] Pautke, C., Bauer, F., Otto, S., et al.: Fluorescence-guided bone resection in bisphosphonate-related osteonecrosis of the jaws: first clinical results of a prospective pilot study. J. Oral Maxillofac. Surg., 2011, 69(1), 84-91.

[23] Voss, P. J., Joshi Oshero, J., Kovalova-Müller, A., et al.: Surgical treatment of bisphosphonate-associated osteonecrosis of the jaw: technical report and follow up of 21 patients. J. Craniomaxillofac. Surg., 2012, 40(8), 719-725.

[24] Ristow, O., Otto, S., Troeltzsch, M., et al.: Treatment perspectives for medication-related osteonecrosis of the jaw (MRONJ). J. Craniomaxillofac. Surg., 2015, 43(2), 290-293.

[25] Thacker, J.: An approach to the mechanism of killing of cells in suspension by ultrasound. Biochim. Biophys. Acta, 1973, 304(2), 240-248.

[26] Blus, C., Szmukler-Moncler, S.: Atraumatic tooth extraction and immediate implant placement with piezosurgery: evaluation of 40 sites after at least 1 year of loading. Int. J. Periodontics Restorative Dent., 2010, 30(4), 355-363.

[27] Kipshidze, N., Nikolaychik, V., Muckerheidi, M., et al.: Effect of short pulsed nonablative infrared laser irradiation on vascular cells in vitro and neointimal hyperplasia in a rabbit balloon injury model. Circulation, 2001, 104(15), 1850-1855.

[28] Ueda, Y., Shimizu, N.: Effects of pulse frequency of low-level laser therapy (LLLT) on bone nodule formation in rat calvarial cells. J. Clin. Laser Med. Surg., 2003, 21(5), 271-277.

[29] Ninomiya, T., Hosoya, A., Nakamura, $H$., et al.: Increase of bone volume by a nanosecond pulsed laser irradiation is caused by a decreased osteoclast number and an activated osteoblasts. Bone, 2007, 40(1), 140-148.

[30] Porcaro, G., Amosso, E., Scarpella, R., et al.: Doxycycline fluorescence-guided Er:YAG laser ablation combined with Nd:YAG/ diode laser biostimulation for treating bisphosphonate-related osteonecrosis of the jaw. Oral Surg. Oral Med. Oral Pathol. Oral Radiol., 2015, 119(1), e6-e12.

[31] Lerman, M. A., Xie, W., Treister, N. S., et al.: Conservative management of bisphosphonate-related osteonecrosis of the jaws: Staging and treatment outcomes. Oral Oncol., 2013, 49(9), 977-983.
(Soós Balázs dr., Pécs, Dischka Győző u. 5., 7621 e-mail: soosbalazsdr@gmail.com) 